\title{
Research on the composite and functional characteristics of leather fiber mixed with nitrile rubber
}

\author{
Jun Guo ${ }^{1,2}$, Rui Dai ${ }^{1,2}$, Hui Chen ${ }^{1,2}$, Yan Liang ${ }^{3}$ and Zhihua Shan ${ }^{1,2^{*}}$
}

\begin{abstract}
The recycling of leather solid waste not only involves resource utilization and environmental protection but also has important significance for the sustainable development of the leather industry. In this paper, the leather waste was crushed into fibers, which were stabilized and mixed with nitrile-butadiene rubber (NBR). The mixture was milled and vulcanized and a composite NBR-SLF (Stabilized Leather Fiber) is prepared for sealing material. The physical and mechanical properties, water resistance, oil resistance and aging resistance of NBR-SLF were tested and analyzed. It is found that the optimized NBR-SLF not only reduces the cost of raw material, but also changes the physical and mechanical performance of NBR. As a sealing material, it satisfies the substitution of NBR in terms of hardness and thermal stability. Especially the anti-aging ability is better than NBR.
\end{abstract}

Keywords: Leather solid waste, Stabilized leather fibers, NBR, Mechanical performance

\section{Introduction}

Chengdu, known as the women's shoe capital of China, is an important production base of women's shoes in China, producing 200 million pairs of leather shoes and boots each year, as well as discharging nearly 10,000 tons of leather solid waste every year. The solid waste from one of the waste collection stations is shown in Fig. 1. Leather solid waste contains $0 \% \sim 3.5 \% \mathrm{Cr}_{2} \mathrm{O}_{3}$ and is determined by the government to be hazardous [1], which is difficult to recycle because of the complex chemical compositions, diverse colors and resin coating on the surface. In order to distinguish the solid leather shavings of the tannery, this paper uses 'LW' to represent this kind of leather solid waste that have been finished (dyed and coated).

\footnotetext{
* Correspondence: Leather512@sohu.com

'National Engineering Research Center of Clean Technology in Leather

Industry, Sichuan University, Chengdu 610065, China

${ }^{2}$ College of Biomass Science and Engineering, Sichuan University, Chengdu 610065, China

Full list of author information is available at the end of the article
}

For many years, conventional treatment methods for LW have been incineration and landfill disposal at home and abroad [2].

Incineration can greatly reduce the volume of LW and the technology cost is relatively low. It can also recycle the energy stored in leather solid waste $[3,4]$. However, there are serious problems with this kind of treatment. For example, harmful gases are produced after incineration, including $\mathrm{SO}_{x}, \mathrm{NO}_{x}$, etc., which pollute the atmosphere and need to be treated by a gas purification device [5]. In addition, the $\mathrm{Cr}$ (III) in leather may be oxidized to toxic $\mathrm{Cr}$ (VI) and leaches into soil and water resources, posing a threat to human health and the environment [6]. Another way to dispose of LW is to bury it in landfills. The landfill method has the advantages of low investment, large treatment capacity, easier operation process, independence from other methods and low transportation cost. However, it also introduces many problems: (1) according to reported statistics, 10 , 000 tons of leather solid waste requires an area of 667 $\mathrm{m}^{2}$ [7]. Thus, land encroachment is a problem, (2) leather solid waste buried in the soil easily causes heavy 


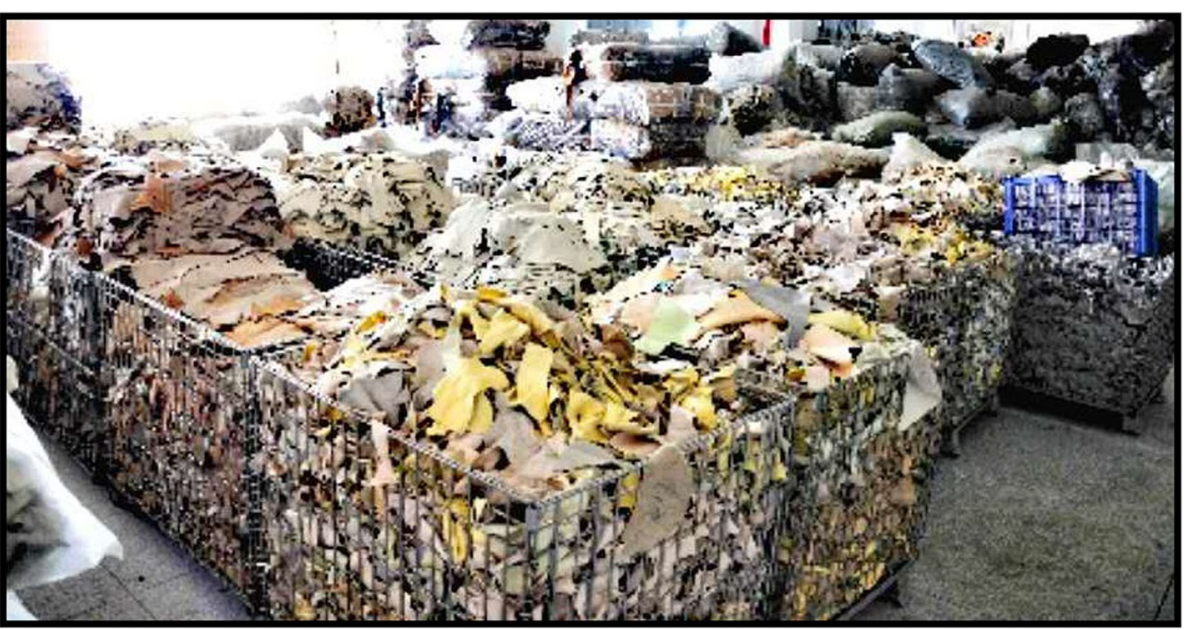

Fig. 1 Collected LW in Chengdu leather market

metal pollution in soil and water [8], and (3) organic compounds in leather solid waste can biodegrade under appropriate environmental conditions, producing harmful gases that pollute the atmosphere.

As far as unfinished leather shavings are concerned, some efficient utilization methods have been reported in recent decades, such as extracting collagen from leather solid waste after $\mathrm{Cr}$ removal [9-12]. The $\mathrm{Cr}$ content of hydrolyzed collagen after treatment with acid, alkali and oxidation was less than $1.5 \times 10^{-7} \mathrm{ppb}$, and the structure of the collagen was not damaged. Therefore, the obtained collagen could be used in the preparation of recombinant collagen, the production of gelatin or gel and in other industrial fields $[9,13]$. Piccin and Oliveira et al. proposed using vegetable tanning and chrome tanning leather solid waste as adsorbents to sequester leather dye, isolate $\mathrm{Cr}^{6+}$ and $\mathrm{As}^{5+}$ in water-borne media in aqueous solutions $[14,15]$.

In consideration of the fact that conventional landfill disposal and incineration may cause a threat to human health and the environment, the recycling and utilization of LW is gaining increasing attention [16], which has been an interesting subject continued for a hundred years. LW mixed with ceramic and glass materials to produce new ceramics and glass is considered to be the most common technique for making hazardous waste inert. However, limited chromium doping can hardly solve all the problems of waste leather [17]. Regenerated leather is a material made of leather solid waste adhered by adhesives. The earlier leather finishing agents have better comminuted or thermoplastic properties. The German company Freudenbeck has been making regenerated leather since 1938 [18]. At present, with the use of PU resin and crosslinking agent, finishing leather crushing becomes difficult. Recycled leather made from solid waste and a large amount of resin has become a feasible LW recovery method. It is a good idea to mix crushed LW with rubber to make a regenerative insole [19].

Nitrile rubber (Nitrile-butadiene rubber, NBR) has always been used as essential elastic material in the automotive, aviation, oil, photocopying and other industries. China needs nearly $2.0 \times 10^{5}$ tons of NBR and imports $50 \%$ a year at close to 3000 dollars a ton. In view of recycling and cost reduction, a new type of heat resistant and flame retardant NBR was prepared by mixing wool keratin powder from tannery waste and rubber raw materials, which is bio-decomposed and is of great importance from the ecological point of view [20] . This paper introduces a method of making rubber material for soft seals and sports mats, in which the crushed and stabilized LW is mixed, refined and vulcanized with rubber.

\section{Experimental}

\subsection{Main materials}

Leather solid waste was obtained from the Chengdu Jinhua leather market waste recycling station $\left(2.14 \% \mathrm{Cr}_{2} \mathrm{O}_{3}\right.$, dried basis). N41 nitrile rubber was provided by Lanzhou Petrochemical Company. Stabilized leather fibers (SLF) were prepared in the lab. Plasticizer DOP (dioctyl phthalate) was from Qingdao Kono Chemical Co. LTD.

\subsection{Crushing of LW}

\subsubsection{Selection of crushing equipment}

The most commonly used crushing methods are hammer crushing and shear crushing. Coated and soft leathers are elastic and thus the shear crushing method should be selected. The working principle of shear crushing equipment is shown in Fig. 2(CXJ500, Zhejiang Fengli, China). The crushing process is easily affected by the high-strength finishing materials on the leather surface. So the leather fibers were homogenized after multiple passes through the crushing shears. 


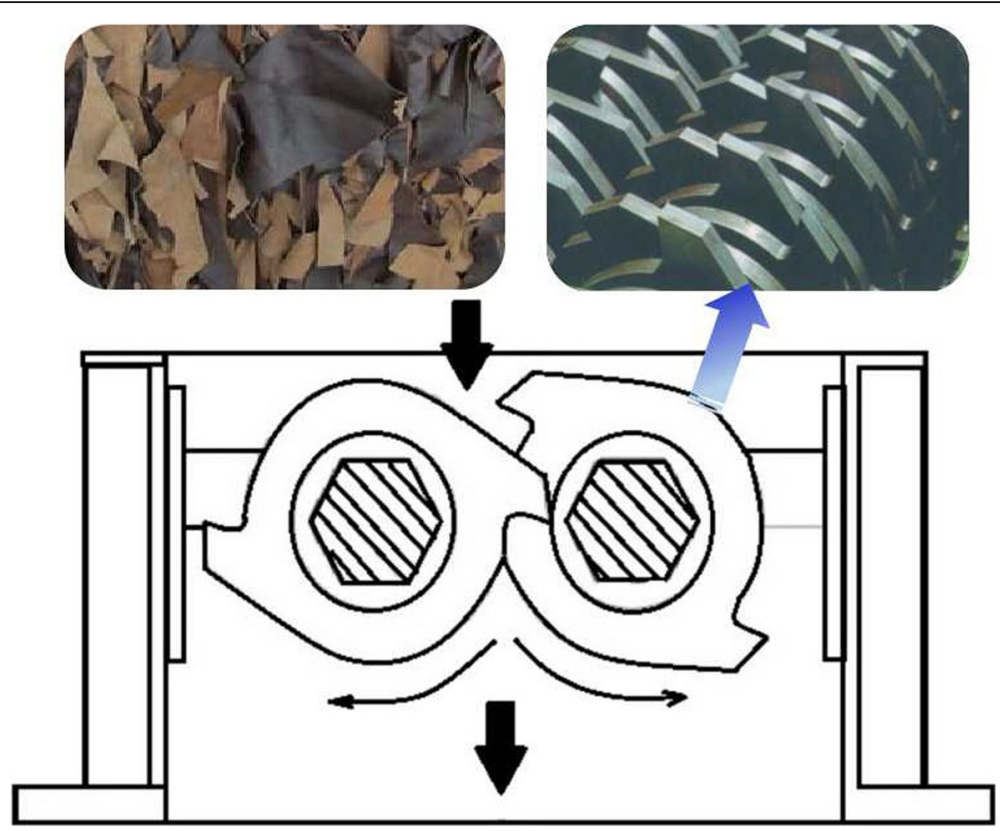

Fig. 2 Partial structure of crushing shears

\subsubsection{Preparation method of experimental LW fibers}

To meet the minimum feed of CXJ500 crushing equipment, $20 \mathrm{~kg}$ of discarded brown garment leathers (less than $0.01 \mathrm{~m}^{2}$ ) from sheep garment factory were crushed under air cooling. The average size of the crushed LW fibers (LF), was $0.3 \sim 0.5 \mathrm{~mm}$ in diameter and $3 \sim 7 \mathrm{~mm}$ in length. The appearance of LF is shown in Fig. 3 (a).

\subsection{Stabilization treatment of LF}

Under proper alkaline conditions, $\mathrm{Cr}$ (VI) is easy to be solidified by hydroxyapatite and $\mathrm{Ca}^{2+}$ ion $[21,22]$. The stabilization method of LF had been confirmed by further research [23]. The TG curve of the LF sample was measured by a thermogravimetric analyzer (TG 209 F3, NETZSCH, Germany). The scanning temperature ranged from $50^{\circ} \mathrm{C}$ to $600{ }^{\circ} \mathrm{C}$, and the heating rate was $10^{\circ} \mathrm{C} / \mathrm{min}$. According to the TG curve, stabilization treatment temperature should be chosen to be $150^{\circ} \mathrm{C}$. After random sampling, LF was placed in a heated drum mixer. Then $30 \%$ water was added and stirred for 30 min, $4 \% \mathrm{Ca}(\mathrm{OH})_{2}$ was added and stirred for $30 \mathrm{~min}$, heated to $150{ }^{\circ} \mathrm{C}$ and stirred again for $30 \mathrm{~min}$. After cooling and crushing, LF was placed in the electrically heated drum mixer again, heated to $150^{\circ} \mathrm{C}$ and stirred for 30 min. Then, the stabilized LF was finally prepared, as shown in Fig. 3(b). Compared with LF, the dimensions of the dehydrated SLF shrink significantly. SLF has particle shape and good fluidity. The hydrophobicity of SLF is obviously enhanced, which is favorable for compatibility with NBR.
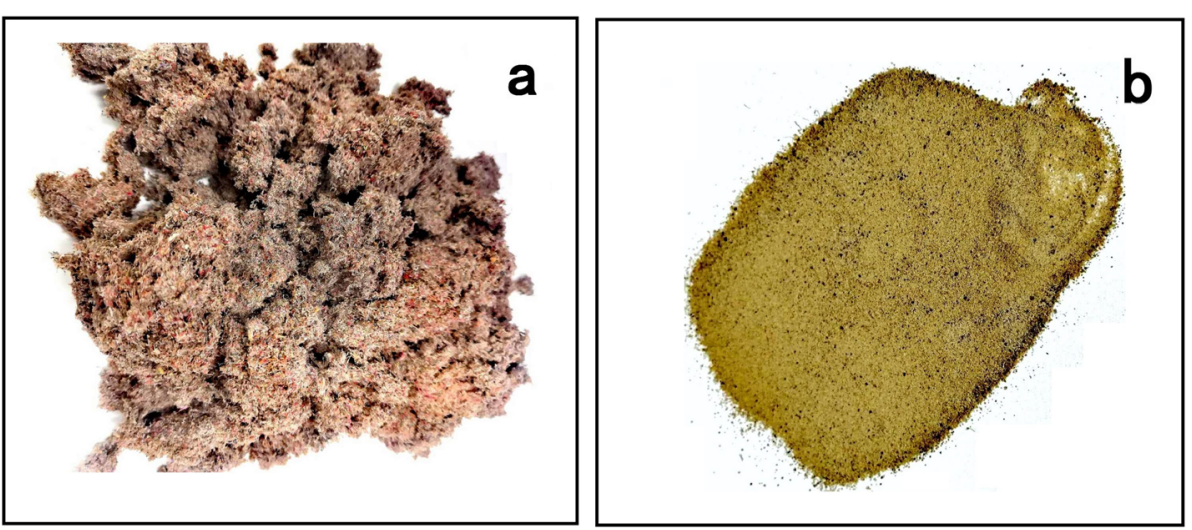

Fig. 3 Appearances of LF (a) and SLF (b) 


\section{4 $\mathrm{Cr}$ leaching of SLF}

SLF leaching experiments were carried out in accordance with two national testing standards: the Horizontal Oscillation Method for "Toxic Leaching of Solid Waste (HJ557-2010)" and the Acetic Acid Buffer Solution Method for "Toxic Leaching of Solid Waste (HJ/T 3002007)". The absorbance of the leach liquor was measured with an ultraviolet-visible spectrophotometer (UV3100PC, Shanghai Mapada, China) at $540 \mathrm{~nm}$ and the Cr (VI) content and total $\mathrm{Cr}$ content were calculated according to a standard curve.

\subsection{Preparation of NBR-SLF composite}

The mixing operation was carried out on an open mill (YC-3203, Yicheng, China). The roll distance was adjusted to $1 \mathrm{~mm}$. Raw NBR rubber was thinned 20 times at $60{ }^{\circ} \mathrm{C}$ and then mixed evenly with SLF and other components. After mixing well, the sample was pressed on a plate vulcanizer (XLB-D350, Ningbo Qianpu, China) with a pressure of $5 \sim 6 \mathrm{MPa}$. Then the sample was removed and cooled to room temperature. NBR-SLF recipe is shown in Table 1 . In this recipe, despite the environmental problems of $\mathrm{ZnO}$, the effects of $\mathrm{ZnO}$ on the mechanical performance of NBR and its antimicrobial properties are still of concern [24]. The optimization was carried out by single factor variable experiment. The initial combination condition was platen press time of $30 \mathrm{~min}$, platen temperature of $150^{\circ} \mathrm{Cand} 15 \mathrm{phr}$ SLF. The single factor variable: the platen press time 10 to 40 min, the platen temperature 130 to $160^{\circ} \mathrm{C}$ and SLF 0 to $50 \mathrm{phr}$.

\subsection{Morphologies observations of NBR-SLF}

The morphologies of the optimized NBR-SLF samples were observed by SEM (JSM-7500F, JEOL, Japan). The samples were sprayed with gold and then the surface morphologies after fracture were observed at $15 \mathrm{kV}$.

\subsection{Mechanical performance test of NBR-SLF}

The tensile strength and elongation at break of the optimized NBR-SLF samples was measured on a universal material tensile testing machine(Instron, USA) in accordance with GB/T528-1998 at a tensile speed of $500 \mathrm{~mm} / \mathrm{min}$. According to GB/T529-1999, the tear strength of the composite was determined. According to GB/T531-1999, the shore A hardness of the composite was determined by a rubber hardness tester (LX-A, Shanghai Liuling, China).

\subsection{Thermal performance of NBR-SLF}

The thermal performance of the optimized NBR-SLF sample was characterized. The temperature of the glass transition, dynamic mechanical properties and thermal stability of the NBR-SLF were investigated. DSC analysis was performed with a differential scanning calorimeter (DSC 200 PC, NETZSCH, Germany) in a $\mathrm{N}_{2}$ atmosphere, from $-80^{\circ} \mathrm{C}$ to $100^{\circ} \mathrm{C}$, at $5^{\circ} \mathrm{C} / \mathrm{min}$. DMA was performed with a dynamic mechanical analyzer (DMA 242, NETZSCH, Germany) from $-80^{\circ} \mathrm{C}$ to $60^{\circ} \mathrm{C}$, at $5^{\circ} \mathrm{C} / \mathrm{min}$ and the frequency was $1 \mathrm{~Hz}$. TG was performed with a thermogravimetric analyzer (TG 209 F3, $\mathrm{NETZSCH}$, Germany) in a $\mathrm{N}_{2}$ atmosphere, from $25^{\circ} \mathrm{C}$ to $600^{\circ} \mathrm{C}$, at $10^{\circ} \mathrm{C} / \mathrm{min}$.

\subsection{Vulcanization characteristics of NBR-SLF}

A rubber vulcanizer(R100E, Beijing Youshen, China) was used to determine the NBR-SLF samples vulcanization curves with different amounts of SLF at $150{ }^{\circ} \mathrm{C}$ for 30 $\mathrm{min}$. The following indicators were measured:

$$
\begin{aligned}
& t_{10} \text { - scorch time } \\
& t_{90} \text { - optimum cure time } \\
& M_{L} \text { - the minimum torque } \\
& M_{H} \text { - the highest torque }
\end{aligned}
$$

\subsection{Resistance of NBR-SLF to media}

Water resistance test: $3 \mathrm{~mm} \times 3 \mathrm{~mm}$ granules were cut from the optimized NBR-SLF sample, weighed, placed into deionized water at $25^{\circ} \mathrm{C}$, removed $48 \mathrm{~h}$ later, dried surface moisture with filter paper and weighed. The water absorption rate $S$ was calculated as follows (1):

$$
s=\frac{m_{0}-m}{m} \times 100 \%
$$

$m$ - the mass before water absorption, g;

$m_{0}$ - the mass after water absorption, $g$.

Oil resistance test: oil resistance was tested in \#20 engine oil according to GB/T 1690-2010. The sample size was $30 \mathrm{~mm} \times 30 \mathrm{~mm} \times 3 \mathrm{~mm}$ and the experimental conditions were $40^{\circ} \mathrm{C} \times 72 \mathrm{~h}$. The oil absorption rate (i.e., mass change rate) was calculated as follows (2):

$$
\Delta m_{100}=\frac{m_{i}-m_{0}}{m_{0}} \times 100 \%
$$

$m_{0}$ - mass of sample in air before soaking, g;

Table 1 NBR-SLF composite recipe

\begin{tabular}{llcccccc}
\hline Component & NBR & ZnO & promoter M & stearic acid & sulfur & Plasticizer DOP & Others \\
\hline Dosage $(p h r)$ & 100 & 5.0 & 0.7 & 0.5 & 3.0 & 40 & 0.7 \\
\hline
\end{tabular}


$m_{\mathrm{i}}$ - mass of sample in air after soaking, $\mathrm{g}$.

Mechanical performance test: the tensile strength, elongation at break and Shore A hardness of materials were tested according to the method outlined in section 2.7 after the sample was dried by air.

\subsection{Resistance of NBR-SLF to aging}

The experimental methods of artificial accelerated aging included carbon arc lamp, ultraviolet light and xenon lamp. Among them, the wavelengths emitted by xenon lamps are mainly distributed in the range of $290 \sim 800$ $\mathrm{nm}$, which is closer to the radiation of sunlight observed on the surface of the earth.

Aging method: the experiments were carried out in a TY/XD-225 l xenon lamp weatherproof test box. The temperature was $25^{\circ} \mathrm{C}$, the relative humidity was $50 \%$, the irradiance was $800 \mathrm{~W} / \mathrm{m}^{2}$ and the illumination time was $150 \mathrm{~h}$.

Mechanical performance test: the tensile strength, elongation at break and Shore A hardness of optimized NBR-SLF sample after aging were tested according to the methods outlined in section 2.7.

\section{Results and discussion}

\section{1 $\mathrm{Cr}$ leaching of SLF}

The surface of the LF will expose $\mathrm{Cr}$ salts, which may lead to the leaching of $\mathrm{Cr}$. Erdem $\mathrm{M}$, et al. studied the leaching behavior of $\mathrm{Cr}$ in leather shavings and proved that the leather shaving is a hazardous material for environment. Thermal stabilization procedure can be applied to the leather shavings for the $\mathrm{Cr}$ immobilization [15]. The data in Table 2 show that the Cr (VI) content $(<5 \mathrm{mg} / \mathrm{L})$ and total $\mathrm{Cr}$ content $(<15 \mathrm{mg} / \mathrm{L})$ of the solution leached from SLF meet the safety requirements of Chinese standard "identification standards for hazardous wastes: Identification for extraction toxicity (GB5085.3-2007)", which is similar to the USEPA standard.

In this study, thermal stabilization procedure with $\mathrm{Ca}$ $(\mathrm{OH})_{2}$ was applied to the LF. Leaching experiments were carried out both in aqueous solution and buffer solution of acetic acid. As shown in Table 2, the total Cr content of the control sample (without stabilization treatment) was $17.34 \mathrm{mg} / \mathrm{kg}$ after acetic acid buffer leaching, which exceeded the national standard. After stabilization treatment, the total $\mathrm{Cr}$ content in SLF leached into the aqueous solution decreased from $13.98 \mathrm{mg} / \mathrm{kg}$ to $5.22 \mathrm{mg} / \mathrm{kg}$ and the total $\mathrm{Cr}$ content in SLF leached into the acetic acid buffer decreased from $17.34 \mathrm{mg} / \mathrm{kg}$ to $7.13 \mathrm{mg} / \mathrm{kg}$.

In fact, the stabilizing mechanism is complex. On the one hand, collagen can form stable hydrophobic complexes with alkaline earth metals and transition metals during dehydration. On the other hand, calcium and chromium can also combine to form stable mineralization products during heating $[25,26]$. Further, in the stabilization process of the LF, it has been shown that the calcium-chromium complex is encapsulated and solidified by molten and dehydrated collagen and lipids (from fatliquor and fat in sheepskin) in SLF, which was confirmed by EDS with chromium on the surface before and after crushing stabilized leather shavings [23]. The super hydrophobicity and anti-acetic acid property of SLF make the leaching of chromium salt difficult to be detected.

\subsection{Optimization of mechanical performance and conditions of NBR-SLF}

The influences of platen press time, platen temperature and SLF amount on the mechanical properties of the NBR-SLF were investigated. In addition to the singlefactor variables, other conditions are based on the initial combination conditions.

Figure 4 lists the mechanical performance of NBR-SLF samples with different platen press time. Figure 4 (b) (c) (d) show that the tear strength, shore A hardness and tensile strength of NBR-SLF increased with platen press time, reached a maximum at $30 \mathrm{~min}$ and began to decrease after $30 \mathrm{~min}$. Figure 4 (d) shows that the modulus of elasticity increased with platen press time, reaching $2.51 \mathrm{MPa}$ at $40 \mathrm{~min}$. With increasing platen press time, rubber molecules gradually crosslinked into a network structure, which enhanced the mechanical properties of the NBR-SLF. As can be seen from Fig. 4(a), the elongation at break of NBR-SLF decreased with platen press time and reached $379 \%$ at $40 \mathrm{~min}$. This may be due to a decrease in the free volume of SLF in the rubber network. Based on the analysis above, $30 \mathrm{~min}$ was selected as the best platen press time.

Figure 5 shows the variation of the mechanical performance of NBR-SLF with platen temperature. It can be seen from Fig. 5 (d) that tensile strength and elastic modulus changed little with platen temperature. Figure 5 (a) shows that the elongation at break increased significantly with platen temperature, reaching $433 \%$ at

Table $2 \mathrm{Cr}(\mathrm{Vl})$ and total $\mathrm{Cr}$ content measured by two leaching methods

\begin{tabular}{|c|c|c|c|c|c|c|}
\hline \multirow[t]{2}{*}{ Leather fiber } & \multicolumn{2}{|c|}{ Aqueous leaching (mg/kg) } & \multicolumn{2}{|c|}{ Acetic acid buffer leaching (mg/kg) } & \multicolumn{2}{|c|}{ National standard $(\mathrm{mg} / \mathrm{kg})$} \\
\hline & $\mathrm{Cr}(\mathrm{VI})$ & Total $\mathrm{Cr}$ & $\mathrm{Cr}(\mathrm{VI})$ & Total $\mathrm{Cr}$ & $\mathrm{Cr}(\mathrm{VI})$ & Total $\mathrm{Cr}$ \\
\hline Control sample & 0.11 & 13.98 & 0.48 & 17.34 & $<5$ & $<15$ \\
\hline SLF sample & 0.51 & 5.22 & 0.79 & 7.13 & $<5$ & $<15$ \\
\hline
\end{tabular}



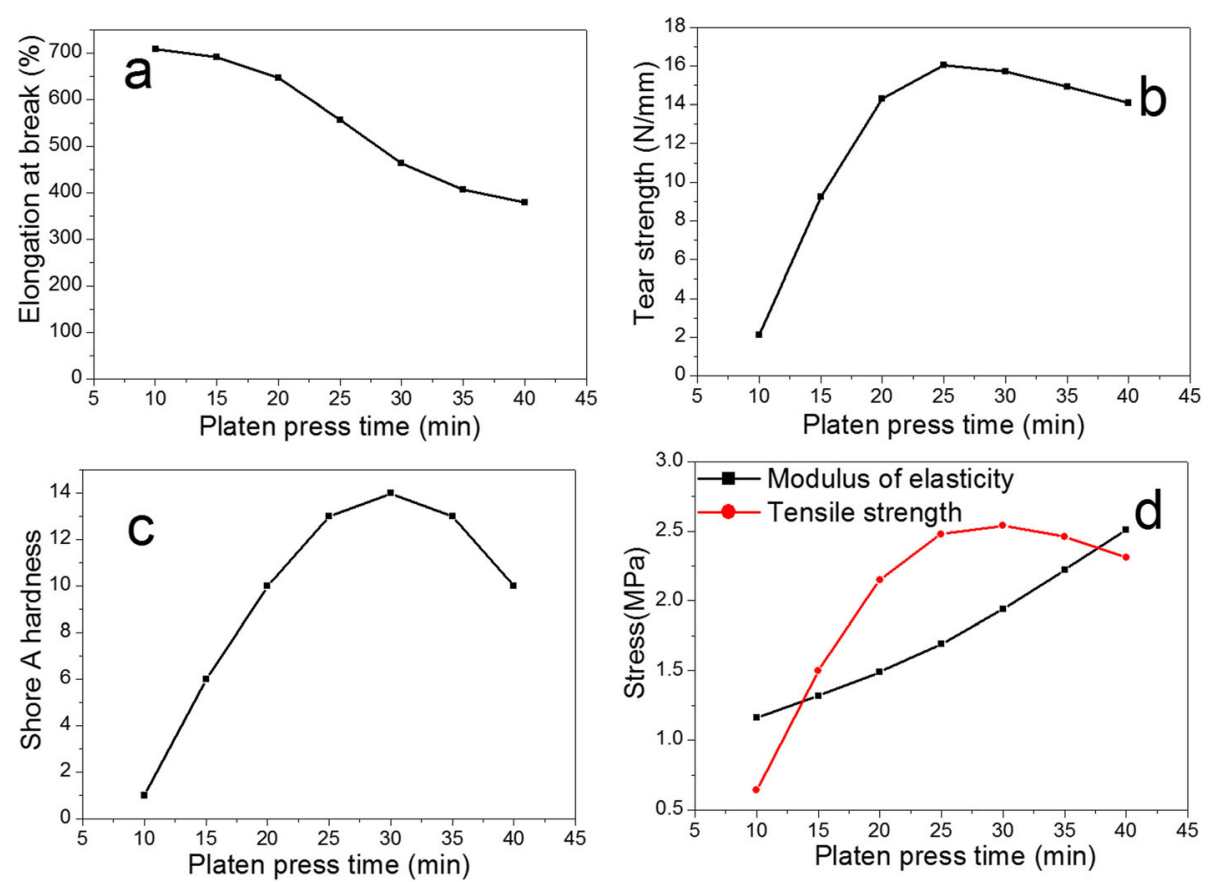

Fig. 4 Effect of platen press time on the mechanical performance

$160^{\circ} \mathrm{C}$. This may be because the higher the platen temperature, the faster the NBR rubber vulcanization rate. Figure 5 (b) shows that the tear strength first increased and then decreased, reaching a maximum value of $20.4 \mathrm{~N} / \mathrm{mm}$ at $150^{\circ} \mathrm{C}$. As shown in Fig. 5 (c) the change of shore A hardness with temperature was not obvious. Overall, the mechanical properties of the samples prepared at $150^{\circ} \mathrm{C}$ were the best.

Figure 6 shows that the elastic modulus and shore A hardness of the NBR-SLF increased significantly
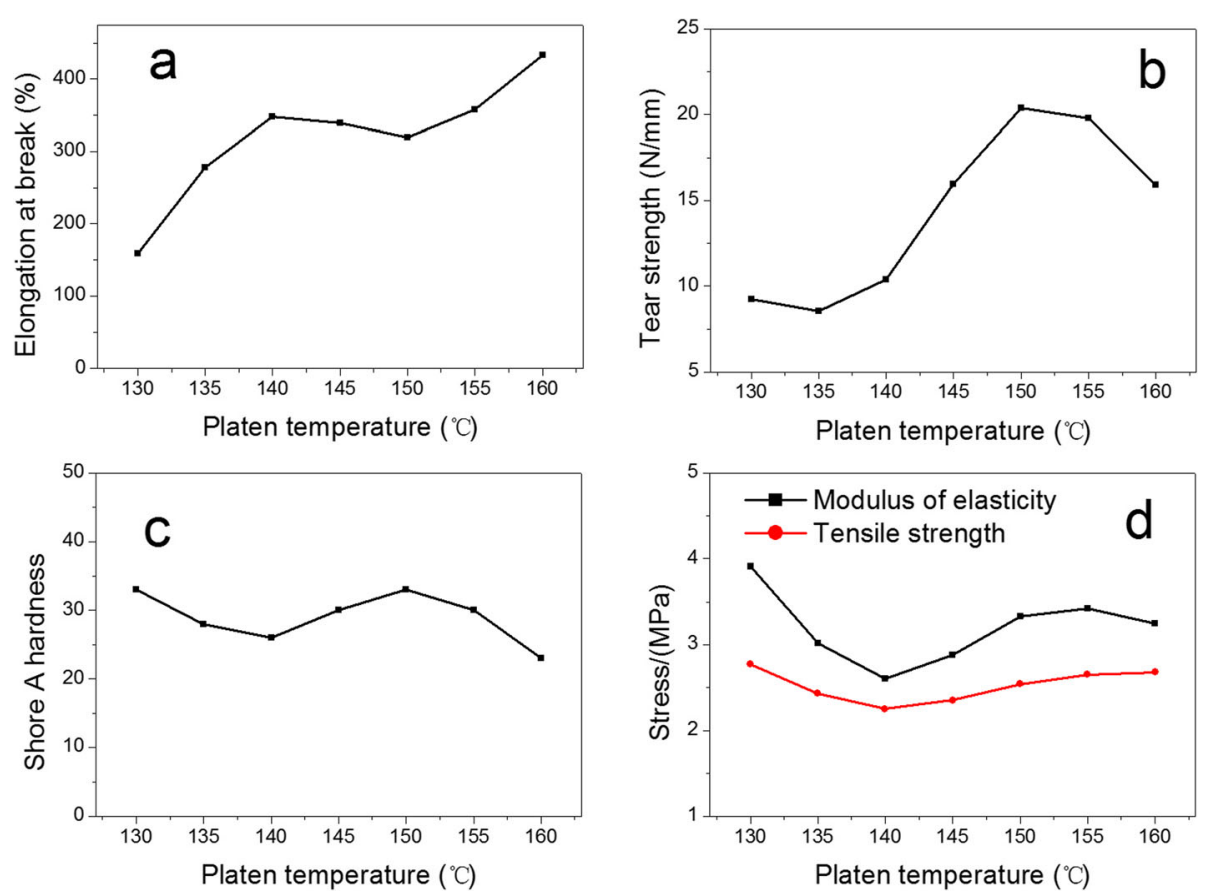

Fig. 5 Effect of platen temperature on the mechanical performance 
with the amount of the SLF added. From 0 to $50 \mathrm{phr}$ SLF, the elastic modulus of NBR-SLF increased from 1.63 $\mathrm{MPa}$ to $5.57 \mathrm{MPa}$ and shore A hardness increased from 13 to $40 \mathrm{HA}$. However, with the increasing SLF amount, the tensile strength and elongation at break of NBR-SLF decreased, which can be seen from Fig. 6 (a) (d). In addition, the tear strength increased with SLF amount, reaching a maximum value at $15 \mathrm{phr}$ SLF. This is probably because SLF exist between rubber molecular chains after filling into the NBR matrix, hindering the movement between chains. When the NBR-SLF was subjected to external stress, the strain decreased, showing high modulus, hardness and low elongation. By comprehensive consideration, the optimal SLF dosage was 15 phr.

As discussed above, the platen press time, platen temperature and SLF amount all have great influence on the mechanical performance of the NBR-SLF. The optimum process conditions were as follows: time 30 min, temperature $150^{\circ} \mathrm{C}$ and $15 \mathrm{phr}$ SLF. The NBR-SLF samples prepared under optimized process conditions are shown in Fig. 7.

\subsection{Morphology of NBR-SLF from SEM}

Observation of the longitudinal section of the optimized NBR-SLF sample was performed via $\operatorname{SEM}(\times 2000)$ and is shown in Fig. 8. The SEM images show that the pores and the two components interfaces exist simultaneously in the NBR-SLF. This phenomenon results from the disharmony between the polar and non-polar regions on the surface of the two components and it is difficult to obtain a close bond between the whole surface. These morphologies make it easy to understand experimental results. On the one hand, the incorporation of SLF reduces the density of the material, leading to the increase of elasticity and the decrease of hardness, which is advantageous to the NBR-SLF composite as a seal material; on the other hand, due to local pores, if SLF is mixed with uneven particle size and distribution, it will lead to severe instability of NBR-SLF strength.

\subsection{Thermal performance of NBR-SLF}

The main NBR chain contains unsaturated bonds, which leads to a high $T_{\mathrm{g}}$ and poor performance at low temperatures. Figure 9 shows the DSC spectra and DMA spectra of NBR and the optimized NBR-SLF sample.

As shown in Fig. 9(a), the $\mathrm{T}_{g}$ of NBR was $-33.6^{\circ} \mathrm{C}$, while the $\mathrm{T}_{\mathrm{g}}$ of the NBR-SLF was $-31.0^{\circ} \mathrm{C}$. The addition of SLF increased the $T_{g}$ of NBR by $2.6^{\circ} \mathrm{C}$. Because the surface of SLF is covered by calcium and chromium bound collagen and grease, thus forming hydrophobicity [27],the formation of a blend polymer by miscibility of the two surfaces of NBR and SLF. The result of the composition is that the addition of collagen fibers with higher $\mathrm{T}_{\mathrm{g}}$ causes the glass transition temperature of compound to increase by blending with NBR [20].

As shown in Fig. 9(b), the peak $\tan \delta$ temperature of NBR was $-19.5^{\circ} \mathrm{C}$ and the peak tan $\delta$ temperature of
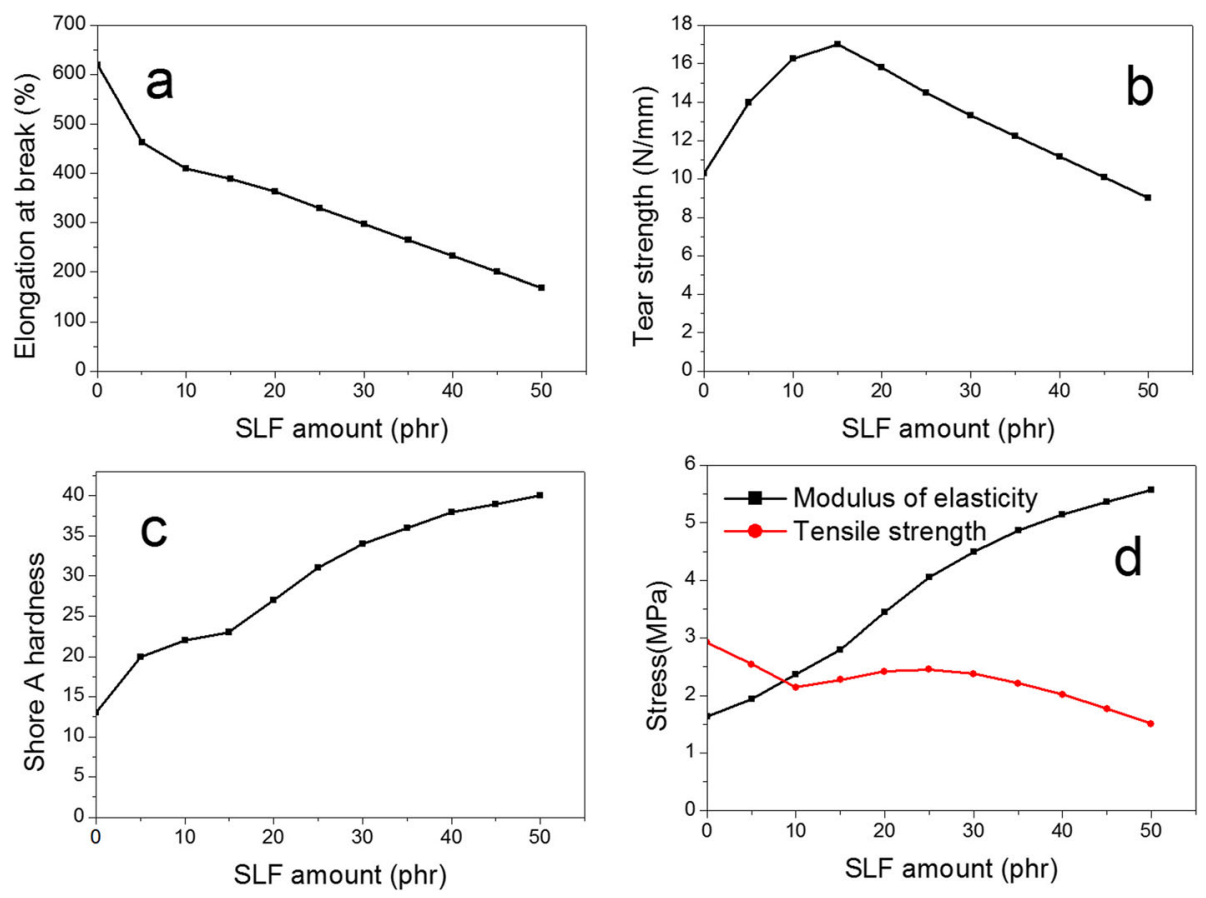

Fig. 6 Effect of SLF addition amount on the mechanical performance 


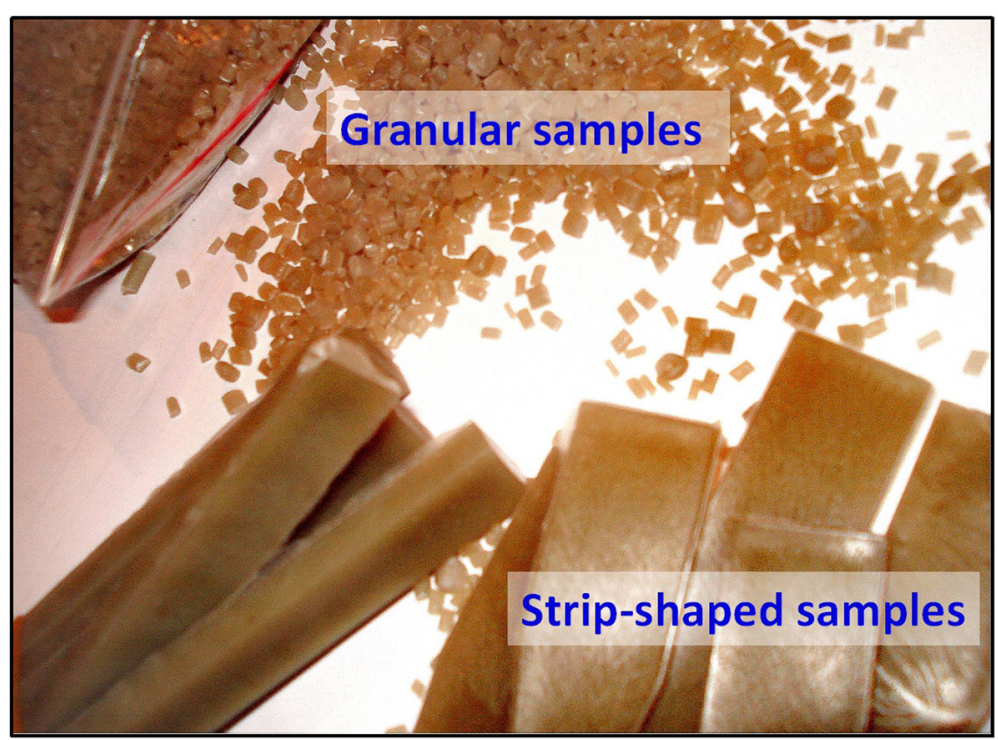

Fig. 7 Optimized NBR-SLF samples

NBR-SLF was $-18.8^{\circ} \mathrm{C}$. This was consistent with the change in $T_{g}$ measured by DSC. The energy storage modulus of NBR-SLF was higher than that of NBR rubber. This indicates that the SLF enhance the rigidity of NBR-SLF, which is consistent with the results of the mechanical properties test. The loss modulus of NBRSLF is smaller than that of the NBR, indicating that after the addition of SLF to NBR, the energy loss decreased. This can indicate that in NBR-SLF, the SLF acts as a valid link to transmit or disperse the energy quickly.

Thermogravimetric analysis was used to determine the thermal degradation temperature of NBR and the optimized NBR-SLF sample to characterize their thermal stability. TG curves are shown in Fig. 10. Comparing these two curves, the initial temperature of weight loss of NBR was $413.0^{\circ} \mathrm{C}$, while that of NBR-SLF was $419.3^{\circ} \mathrm{C}$. When SLF was added to NBR, the initial temperature of weight loss increased by $6.3^{\circ} \mathrm{C}$ and the thermal stability of the composite was enhanced. The curing process and hydrogen bonding between NBR and SLF enhance the interaction between molecules and increase the rigidity of NBR-SLF [28]. See Fig. 9 and Fig. 10, the thermal performances of the NBR-SLF and NBR are different. Although it is impossible to prove whether cross-linking has occurred within NBR-SLF or whether that form of chemical reaction has occurred, the combination between the two components does exist $[20,29]$. In addition, the residual mass of NBR and
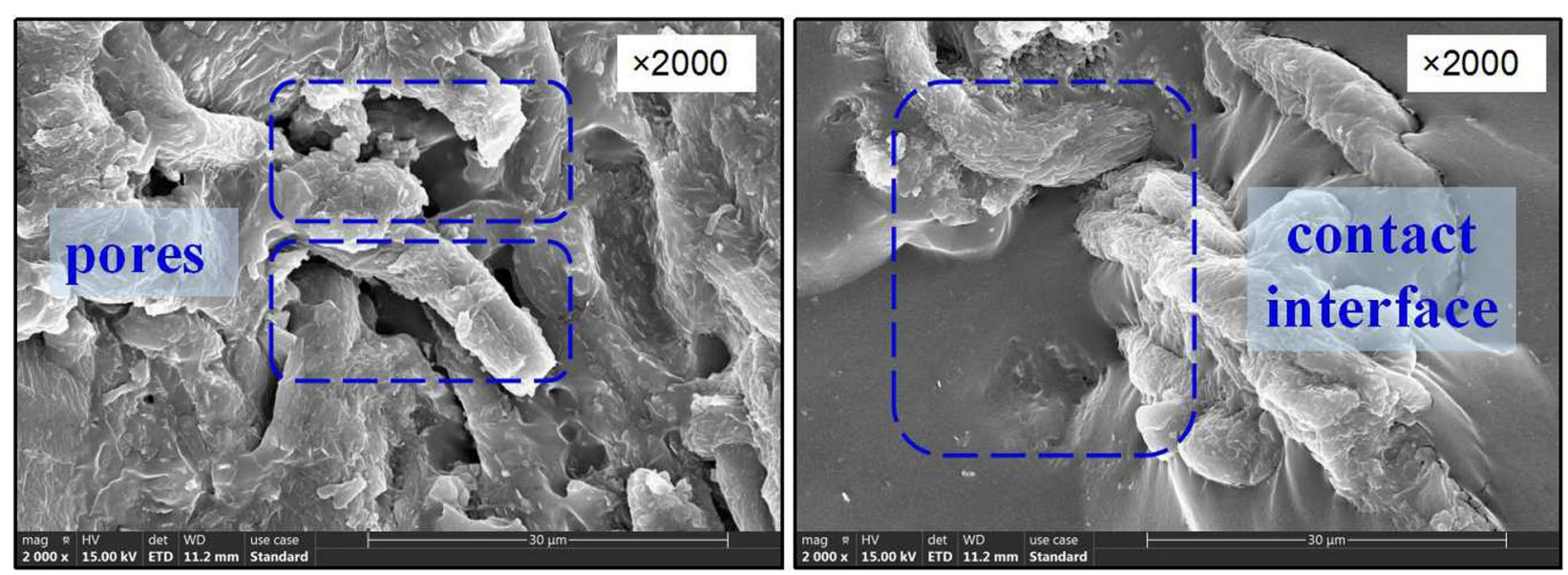

Fig. 8 SEM images of the optimized NBR-SLF sample 

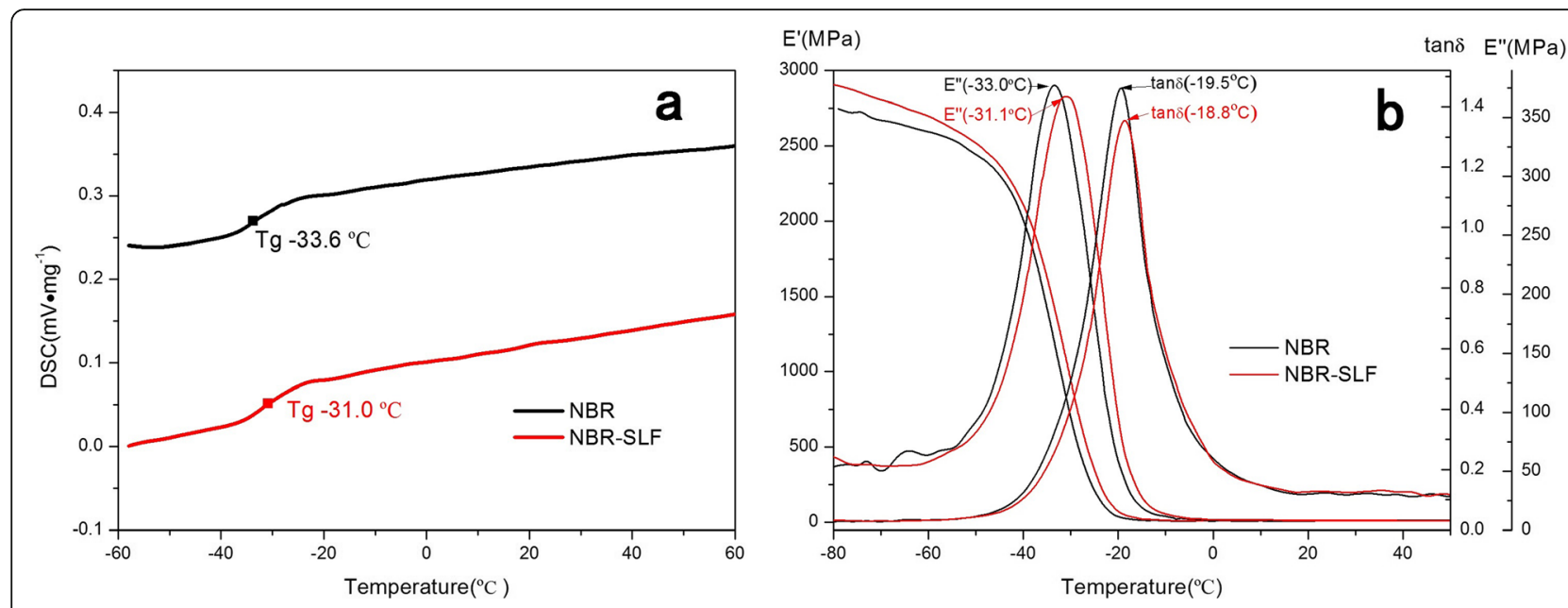

Fig. 9 DSC spectra (a) and DMA spectra (b) of NBR and NBR-SLF

NBR-SLF was $8 \%$ and $11 \%$ respectively, which may be caused by the residue of inorganic salts and metal oxides in them.

\subsection{Vulcanization characteristics of NBR-SLF}

The vulcanization curves of NBR-SLF mixed with $0 \mathrm{phr}$, $10 \mathrm{phr}$ and $20 \mathrm{phr}$ SLF are shown in Fig. 11.

As shown in Fig. 11, as the SLF amount increased, the $\mathrm{M}_{\mathrm{L}}$ and $\mathrm{M}_{\mathrm{H}}$ of the NBR-SLF increased. Moreover, the curing rate increased significantly with increasing SLF amount, which shows that there must be some sensitivity between SLF and collagen during vulcanization and hardening. This phenomenon has also been reported, which proved the cross-linking between proteins is produced during the vulcanization process [30].
Table 3 shows the effect of SLF amount on the curing characteristics of NBR-SLF. As shown in Table 3, the SLF filling can greatly shorten $t_{10}$ and $t_{90}$, reducing curing time and improve curing efficiency. When the SLF amount increased from 0 to $20 \mathrm{phr}$, the $\mathrm{M}_{\mathrm{L}}$ increased by $77.8 \%$ and the $\mathrm{M}_{\mathrm{H}}$ increased by $33.3 \%$, indicating that the addition of SLF greatly increased the crosslinking density in NBR-SLF. This may be because the polar or nonpolar groups in SLF form bonds with the side chains of NBR molecules, strengthening the intermolecular connections.

\subsection{Resistance of NBR-SLF to media}

Resistance of NBR-SLF to water and oil dipping are important performance of soft NBR-SLF including the

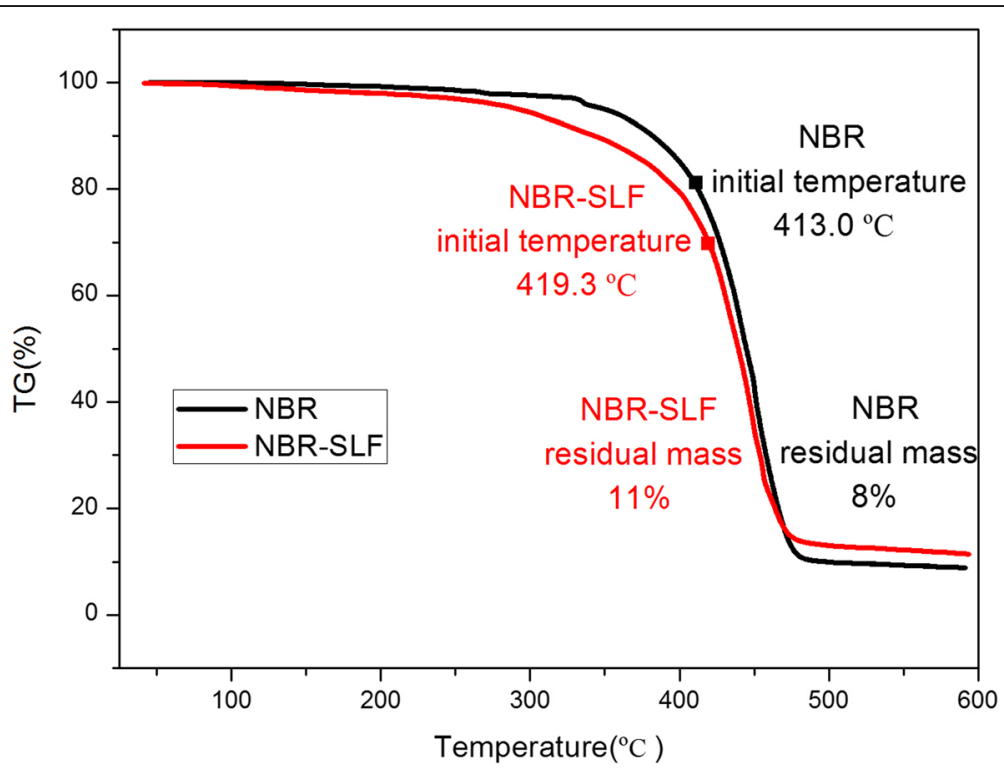

Fig. 10 TG curves of NBR and NBR-SLF 


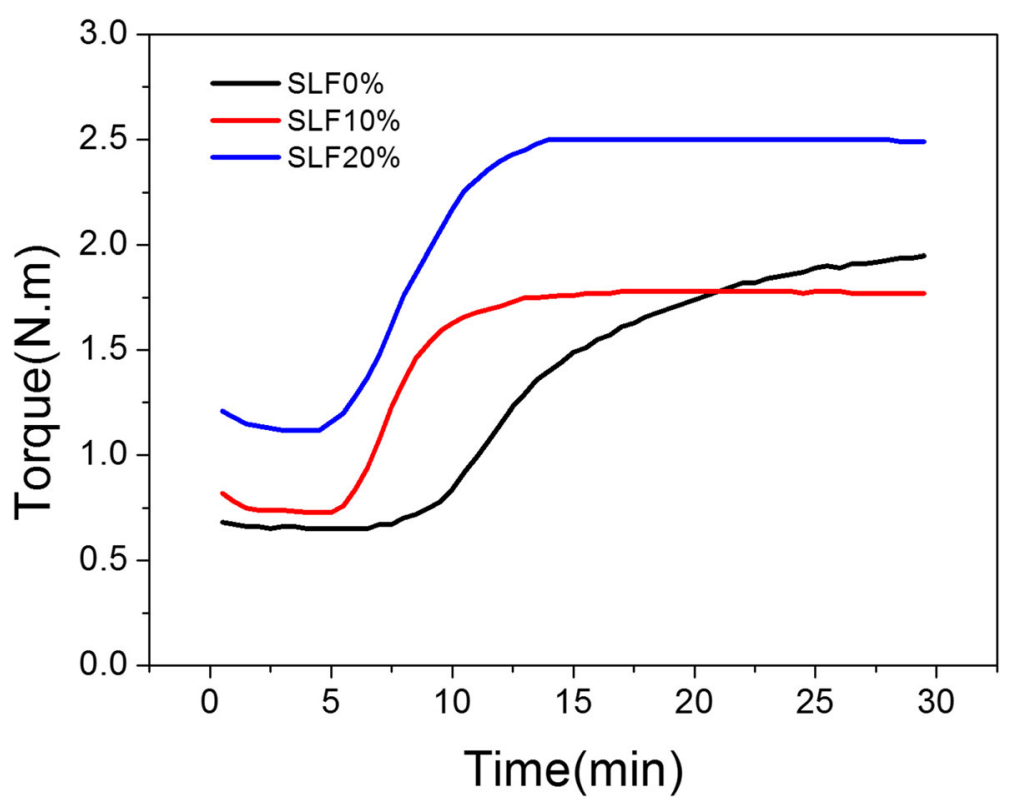

Fig. 11 Vulcanization curve of NBR-SLF vary with SLF amounts

absorption of water or oil and the change of tensile strength, elongation at break and shore A hardness before and after immersion. The results are shown in Table 4.

As shown in Table 4, after immersion in water, the water absorption rates of NBR and NBR-SLF were 5.3\% and $8.4 \%$ respectively. This may be because the addition of SLF slightly improved the hydrophilicity of the material. After immersion in water, the tensile strength, elongation and hardness of NBR or NBR-SLF all reduced to some extent. After immersion in oil, the oil absorption rates of NBR and NBR-SLF were $6.2 \%$ and $4.7 \%$ respectively, which is related to SLF. On the contrary, the relatively good oil resistance of NBR-SLF also comes from the addition of SLF, which enhances the resistance to nonpolar solvents. However, the breaking elongation of NBR-SLF is significantly lower than that of NBR, which is attributed to the lack of two-component mixing uniformity. The stress concentration appears at some defective junctions of two surfaces, as shown in the SEM images.

Table 3 Effect of SLF amount on curing NBR-SLF

\begin{tabular}{llll}
\hline $\begin{array}{l}\text { Vulcanization } \\
\text { indicators }\end{array}$ & \multicolumn{3}{l}{ SLF amount } \\
\cline { 2 - 4 } & $\mathbf{0 ~} \mathbf{p h r}$ & $\mathbf{1 0} \mathbf{~ p h r}$ & $\mathbf{2 0} \mathbf{~ p h r}$ \\
\hline $\mathrm{t}_{10} / \mathrm{min}$ & 9.52 & 6.05 & 6.08 \\
$\mathrm{t}_{90} / \mathrm{min}$ & 22.67 & 10.82 & 13.72 \\
$\mathrm{M}_{\llcorner} /(\mathrm{dN} \cdot \mathrm{m})$ & 0.63 & 0.71 & 1.12 \\
$\mathrm{M}_{\mathrm{H}} /(\mathrm{dN} \cdot \mathrm{m})$ & 1.98 & 1.78 & 2.64 \\
\hline
\end{tabular}

\subsection{Resistance of NBR-SLF to aging}

The test results of tensile strength, elongation at break and shore A hardness of NBR and the optimized NBRSLF sample before and after aging test are shown in Table 5. As shown in Table 5, the tensile strength and shore A hardness of NBR and NBR-SLF both increased compared with those observed before aging and the elongation at break significantly decreased.

The increase of crosslinking density is the normal behavior of NBR after aging and NBR-SLF has had similar result [31]. The increase in strength and hardness, as well as the decrease in breaking elongation are attributed

Table 4 Experimental physical parameters of NBR-SLF

\begin{tabular}{|c|c|c|c|c|c|}
\hline Samples & $\begin{array}{l}\mathrm{S} \\
1 \%\end{array}$ & $\begin{array}{l}\Delta \mathrm{M}_{100} \\
/ \%\end{array}$ & $\begin{array}{l}\text { Tensile } \\
\text { strength } \\
\text { /MPa }\end{array}$ & $\begin{array}{l}\text { Elongation } \\
\text { at break } \\
1 \%\end{array}$ & $\begin{array}{l}\text { Shore A } \\
\text { Hardness / } \\
\text { HA }\end{array}$ \\
\hline $\begin{array}{l}\text { NBR } \\
\text { before immersion }\end{array}$ & - & - & 2.90 & 625 & 12 \\
\hline $\begin{array}{l}\text { NBR-SLF } \\
\text { before immersion }\end{array}$ & - & - & 2.37 & 405 & 23 \\
\hline $\begin{array}{l}\text { NBR } \\
\text { after immersion in } \\
\text { water }\end{array}$ & 5.3 & - & 2.68 & 593 & 10 \\
\hline $\begin{array}{l}\text { NBR-SLF } \\
\text { after immersion in } \\
\text { water }\end{array}$ & 8.4 & - & 2.30 & 388 & 21 \\
\hline $\begin{array}{l}\text { NBR } \\
\text { after immersion in } \\
\text { oil }\end{array}$ & - & 6.2 & 2.75 & 607 & 11 \\
\hline $\begin{array}{l}\text { NBR-SLF } \\
\text { after immersion in } \\
\text { oil }\end{array}$ & - & 4.7 & 2.28 & 397 & 22 \\
\hline
\end{tabular}


Table 5 Aging resistance of the NBR-SLF

\begin{tabular}{llll}
\hline Samples & $\begin{array}{l}\text { Tensile strength } \\
\text { /MPa }\end{array}$ & $\begin{array}{l}\text { Elongation } \\
\text { at break/\% }\end{array}$ & $\begin{array}{l}\text { Shore A } \\
\text { Hardness / HA }\end{array}$ \\
\hline NBR before aging & 2.98 & 615 & 13 \\
NBR-SLF before aging & 2.30 & 388 & 24 \\
NBR after aging & 3.05 & 470 & 16 \\
NBR-SLF after aging & 2.42 & 332 & 30 \\
\hline
\end{tabular}

to crosslinking after aging. According to the data in Table 3, compared with NBR, NBF-SLF has small changes in these physical and mechanical properties, which shows that the aging resistance of NBR-SLF was improved by SLF incorporation. This result can be considered to have some relation with the anti-aging property of SLF [32].

\section{Conclusion}

In this study, a method for preparing new composite materials with NBR and leather fibers was studied, which also offers opportunities for recycling leather solid waste. In fact, it is found that the NBR-SLF prepared by blending NBR with leather fibers not only reduces the cost of raw materials, but also changes the physical and mechanical properties of NBR. As a soft rubber material, NBR-SLF can replace NBR to manufacture soft seals and sports mats according to the physical performancetested in the experiments. Moreover, the anti-aging ability is better than NBR. After stabilization treatment of leather fibers, the NBR-SLF composite has a good use safety.

\section{Abbreviations}

LW: leather solid waste that have been finished; LF: crushed LW fibers; NBR: nitrile-butadiene rubber; SLF: stabilized leather fiber;

TG: thermogravimetric; SEM: scanning electron microscopy; DSC: differential scanning calorimetry; DMA: dynamic mechanical analysis

\section{Acknowledgements}

This work was supported by the Chengdu Science and Technology Plan Project (2018-YF05-01219-SN). The authors gratefully acknowledge the Guangdong Defu Leather Products Company for their help with NBR-SLF preparation.

\section{Authors' contributions}

JG performed the experiments and wrote the manuscript. ZS was responsible for designing the experiments and revising the manuscript. RD \& $\mathrm{HC}$ supervised the project and revised the manuscript. $\mathrm{YL}$ helped revise the manuscript. All authors discussed the results and commented on the manuscript. The author(s) read and approved the final manuscript.

\section{Funding}

The support from Chengdu Science and Technology Plan Project (2018YF05-01219-SN) is gratefully acknowledged.

\section{Availability of data and materials}

All data from this study are presented in the paper.

\section{Declarations}

\section{Competing interests}

The authors declare that they have no competing interests.

\section{Author details}

'National Engineering Research Center of Clean Technology in Leather Industry, Sichuan University, Chengdu 610065, China. ${ }^{2}$ College of Biomass Science and Engineering, Sichuan University, Chengdu 610065, China. ${ }^{3}$ Institute for Frontier Materials, Deakin University, Geelong, Victoria 3125, Australia.

Received: 27 May 2020 Accepted: 21 February 2021

Published online: 15 May 2021

\section{References}

1. Qiang T, Ren L. Development of efficiently reusing chrome shavings. Leather Chemicals. 2004;21:5-8.

2. Guan YP, Liu CQ, Peng QF, Zaman F, Zhang H, Jin ZQ, et al. Pyrolysis kinetics behavior of solid leather wastes. Waste Manag. 2019;100:122-7.

3. Dettmer A, Nunes KGP, Gutterres M, Marcilio NR. Obtaining sodium chromate from ash produced by thermal treatment of leather wastes. Chem Eng J. 2010;160:8-12.

4. Dettmer A, Nunes KGP, Gutterres M, Marcilio NR. Production of basic chromium sulfate by using recovered chromium from ashes of thermally treated leather. J Hazard Mater. 2010;176:710-4.

5. Kluska J, Turzynski T, Kardas D. Experimental tests of co-combustion of pelletized leather tannery wastes and hardwood pellets. Waste Manag. 2018;79:22-9.

6. Bahillo A, Armesto L, Cabanillas A, Otero J. Thermal valorization of footwear leather wastes in bubbling fluidized bed combustion. Waste Manag. 2004; 24:935-44.

7. Shang YM. Study on preparation and biodegradability evaluation of the sizing agent for papers based on leather wastes. Xian: Shanxi University of Science and Technology; 2016.

8. Wang L, Li J, Jin Y, Chen M, Luo JH, Zhu XH, et al. Study on the removal of chromium (III) from leather waste by a two-step method. J Ind Eng Chem. 2019:79:172-80.

9. Cot J, Aramon C, Baucells M, Lacort G, Roura M. Waste processing in the tannery: production of gelatin, reconstituted collagen and glue from chrome-tanned leather splits and trimmings subjected to a modified detanning process. J Soc Leath Tech Ch. 2014;70:69-76.

10. Cot J, Aramon C, Baucells M, Lacort G, Roura M. Recovery of collagen Hydrolysate from chrome leather shaving tannery waste through two-step hydrolysis using magnesium oxide and bating enzyme. J Soc Leath Tech Ch. 2019;103:80-4

11. Cabeza LF, Taylor MM, Brown EM, Marmer WN. Chemical and physical properties of protein products isolated from chromium-containing leather waste using two consecutive enzymes [J]. J Soc Leath Tech Ch. 1998;82: 173-9.

12. Taylor MM, Diefendorf EJ, Na GC, Marmer WN. Enzymatic processing of materials containing chromium and protein; 1992. US

13. Nogueira FGE, do Prado NT, Oliveira LCA, Bastos ARR, Lopes JH, de Carvalho JG. Incorporation of mineral phosphorus and potassium on leather waste (collagen): a new Ncollagen PK-fertilizer with slow liberation. J Hazard Mater. 2010;176:374-80.

14. Piccin JS, Gomes CS, Feris LA, Gutterres M. Kinetics and isotherms of leather dye adsorption by tannery solid waste. Chem Eng J. 2012;183:30-8.

15. Oliveira DOL, Goncalves M, Oliveira LCA, Guilherme LRG. Removal of as( $(\mathrm{V})$ and $\mathrm{Cr}(\mathrm{VI})$ from aqueous solutions using solid waste from leather industry. J Hazard Mater. 2008;151:280-4.

16. Liu BH, Li YJ, Wang Q, Bai SB. Green fabrication of leather solid waste/ thermoplastic polyurethanes composite: physically de-bundling effect of solid-state shear milling on collagen bundles. Compos Sci Technol. 2019; 181:1-6.

17. Pelino M. Recycling of zinc-hydrometallurgy wastes in glass and glass ceramic materials. Waste Manag. 2000;20:561-8.

18. Brown EM, Taylor MM, Marmer WN. Production and potential use of coproducts from solid tannery waste [J]. J Am Leather Chem As. 1996;91:270-6.

19. Tatano F, Acerbi N, Monterubbiano C, Pretelli S, Tombari L, Mangani F. Shoe manufacturing wastes: characterisation of properties and recovery options. Resour Conserv Recy. 2012;66:66-75.

20. Janowska G, Kucharska-Jastrzabek A, Prochon M, Przepiorkowska A. Thermal properties and combustibility of elastomer-protein composites. J Therm Anal Calorim. 2013;113:933-8. 
21. Chen ZX, Zheng BY, Fu ML, Li XX, Chen ZB. The sorption of chromium (VI) on nano-hydroxyapatite in simulated chromium (VI) wastewater. J Shandong Univ Technol (JCR-SCI). 2010;24:20-2.

22. Yuan Q, Shen XD, Xue HJ, Li GF, Xiong L, Zou YX. Study on curing effect and micropore characteristics of chromium-polluted soil under the coupling effect of cement and quicklime. J Agro-Environ Sci. 2018:37:1141-8.

23. Yang JG, Shan ZH, Zhang YW, Chen LW. Stabilization and cyclic utilization of chrome leather shavings. Environ Sci Pollut R. 2019;26:4680-9.

24. Threepopnatkul P, Kulsetthanchalee $\mathrm{C}$. Effect of $\mathrm{ZnO}$ and $\mathrm{TiO}_{2}$ on properties of polystyrene/nitrile rubber electrospun fiber mats. 5th Thailand international nanotechnology conference (NanoThailand). Nakhon Ratchasima. Mat Today-Proc. 2018;5:10917-24.

25. Andros L, Juric M, Popovic J, Pajic D, Zadro K, Molcanov K, et al. 1D Heterometallic oxalate compounds as precursors for mixed $\mathrm{Ca}-\mathrm{Cr}$ oxides synthesis, structures, and magnetic studies. Eur J Inorg Chem. 2014;33:5703-13.

26. El-Sheikh SM, Rabah MA. Optical properties of calcium chromate 1Dnanorods synthesized at low temperature from secondaryresources. Opt Mater. 2014;37:235-40

27. Xu WX, Zeng H, Zhou JF, Wang YN, Shi B. Modification of fatliquored split by in-situ polymerization of n-butyl-methacrylate. J Soc Leath Tech Ch. 2017;101:72-7.

28. Shangguan $Y$, Yang J, Zheng Q. Rheology of nitrile rubber with hybrid crosslinked network composed of covalent bonding and hydrogen bonding. RSC Adv. 2017;7:15978-85.

29. Taib MNAM, Yehye WA, Julkapli NM. Influence of crosslinking density on antioxidant nanocellulose in bio-degradation and mechanical properties of nitrile rubber composites. Fiber Polym. 2019;20:165-76.

30. Pan YK, Wang XH, Yuan QL. Thermal, kinetic, and mechanical properties of glycerol-plasticized wheat gluten. J Appl Polym Sci. 2011;121:797-804.

31. Liu J, Li XB, Xu LK, Zhang PQ. Investigation of aging behavior and mechanism of nitrile-butadiene rubber (NBR) in the accelerated thermal aging environment. Polym Test. 2016;54:59-66.

32. Serweta W, Wojcik J, Rutowicz J, Olejniczak Z. Influence of UV aging on some rheological properties of footwear leather. Polymery. 2019;64:617-24.

\section{Publisher's Note}

Springer Nature remains neutral with regard to jurisdictional claims in published maps and institutional affiliations.

\section{Submit your manuscript to a SpringerOpen ${ }^{\odot}$ journal and benefit from:}

- Convenient online submission

- Rigorous peer review

- Open access: articles freely available online

- High visibility within the field

- Retaining the copyright to your article

Submit your next manuscript at $\boldsymbol{\nabla}$ springeropen.com 